\title{
Spectroscopic and Thermogravimetric Investigation of Cd(II) Dinonyldithiophosphate: Removal of Cadmium from Aqueous Solutions
}

\author{
Nermin Biricik, ${ }^{1}$ Hadice Budak Gümgüm, ${ }^{2}$ and Bahattin Gümgüm1 \\ ${ }^{1}$ Department of Chemistry, Faculty of Science, Dicle University, 21280 Diyarbakir, Turkey \\ ${ }^{2}$ Department of Physics, Faculty of Science, Dicle University, 21280 Diyarbakir, Turkey \\ Correspondence should be addressed to Hadice Budak Gümgüm; hbudakg@gmail.com
}

Received 22 January 2015; Revised 1 April 2015; Accepted 1 April 2015

Academic Editor: Henryk Kozlowski

Copyright (C) 2015 Nermin Biricik et al. This is an open access article distributed under the Creative Commons Attribution License, which permits unrestricted use, distribution, and reproduction in any medium, provided the original work is properly cited.

Dinonyldithiophosphoric acid (HDDTP) was synthesised from the reaction of phosphorus pentasulphide and nonyl alcohol. Dinonyldithiophosphate complex of cadmium $\left[\mathrm{Cd}(\mathrm{DDTP})_{2}\right]$ was prepared by mixing solutions of Cd(II) with HDDTP in ethanol at room temperature. The acid and its complex were characterised by elemental analysis and spectroscopy. The thermal behaviour of $\mathrm{Cd}(\mathrm{DNDTP})_{2}$ was investigated by thermogravimetric analysis. Removal of Cd(II) from aqueous media by HDDTP solution was also studied. The optimum conditions for removal of $\mathrm{Cd}$ (II) were investigated for effects of solvent, $\mathrm{pH}$, contact time, concentration, and inorganic anions. $\mathrm{Cd}(\mathrm{II})$ was quantitatively removed from aqueous solutions at the $\mathrm{pH}$ range of $0.5<\mathrm{pH}<6$, under the conditions that the stoichiometric ratio of HDDTP/Cd(II) $\geq 2 / 1$. It can be stated that contact of the Cd(II) with HDDTP was sufficient for quantitative removing of cadmium from acidic aqueous solutions.

\section{Introduction}

Organodithio compounds are widely used in chemical and industrial applications [1-3]. Due to the synthesis and purifying challenges of long chains dialkyldithiophosphoric acids, their use in experiments was rare $[2,4]$, although long chains dialkyldithiophosphoric acids are more easily transferred into the organic phase [5] and more stable against hydrolysis than the short-chain ones [6]. The well-known lubricant zinc dialkyldithiophosphate (ZDDTP) has been extensively investigated [7], but only a few articles have been published on the thermal properties of the other heavy metal dialkyldithiophosphates $[8,9]$. Similarly, there are only a few studies on Cd(II) dialkyldithiophosphates for its removal from aqueous solutions [10-14], but there are no articles on $\mathrm{Cd}(\mathrm{II})$ dinonyldithiophosphate.

Cadmium is one of the most toxic heavy metals for living organisms. One of the important natural heavy metal pollution sources is phosphate rocks/phosphorus fertilizers. During the production of phosphorus fertilizers, dangerous amounts of heavy metals pollute the environment. The main source of cadmium accumulation in the agricultural lands is the phosphorus fertilizers and its restriction is almost impossible [15]. Thus, cadmium is one of the common environmental contaminants and widely distributed around the world.

The other important pollution sources are different industrial activities such as plating of metal, mining, pigments, polyvinyl chloride plastics, petrochemicals, alloy and steel industries, and municipal discharge-wastewater [16]. According to the international standards the threshold level of Cd(II) concentration should be lower than $0.01 \mathrm{mg} / \mathrm{L}$ in wastewater used for irrigation [17]. Therefore it is necessary to eliminate $\mathrm{Cd}(\mathrm{II})$ from contaminated waters.

Because of its high mobility in soil and plant system and easy accumulation, cadmium may cause toxicities such as cancer (lung and prostate), kidney damage, and bone diseases [18]. To reduce or remove Cd(II) from wastewater or contaminated waters, various methods have been developed including adsorption [19-22], biosorption [23, 24], ion exchange [25], hydrogel [26], and chemical precipitationextraction [27]. 


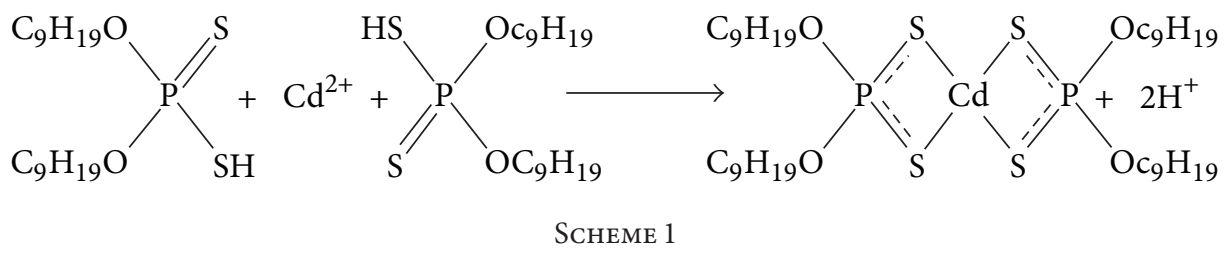

In the present study, dinonyldithiophosphoric acid and its complex of $\mathrm{Cd}$ (II) were prepared and characterised by spectroscopic techniques and thermal analysis. The removal of $\mathrm{Cd}$ (II) from aqueous solutions by using dinonyldithiophosphoric acid was investigated.

\section{Materials and Methods}

2.1. Preparation and Characterisation of HDDTP and $C d(D D T P)_{2}$. HDDTP was prepared from the reaction of phosphorus pentasulphide and nonyl alcohol by using a microwave oven (CEM-MDS 2000, Matthews, USA) according to a previously published method [5] and, to make a sufficiently pure compound, the method described in the literature [6] was modified. The obtained mixture was cooled and the unreacted solid part was filtered. The oily acid was converted to calcium salt by neutralisation with lime slurry at room temperature. The salt was separated and washed with hexane and acidified with $3 \mathrm{M} \mathrm{H}_{2} \mathrm{SO}_{4}$. The free dinonyldithiophosphoric acid floating on top of aqueous phase was separated as a yellowish-green viscous liquid with $98 \%$ purity:

$$
4 \mathrm{C}_{9} \mathrm{H}_{19} \mathrm{OH}+\mathrm{P}_{2} \mathrm{~S}_{5} \longrightarrow 2\left(\mathrm{C}_{9} \mathrm{H}_{19} \mathrm{O}\right)_{2} \mathrm{PSSH}+\mathrm{H}_{2} \mathrm{~S}
$$

An adequate amount of $10^{-2} \mathrm{M}$ solutions of viscous oil HDDTP and Cd(II) in ethanol is mixed at room temperature, and $\mathrm{Cd}(\mathrm{DDTP})_{2}$ was obtained as white precipitate with melting point $28.5^{\circ} \mathrm{C}$ (see Scheme 1).

The prepared acid and its complex were characterised by elemental analysis (EA), ultraviolet-visible (UV-vis), infrared (IR) spectrophotometers, and inductively coupled plasmaoptical emission spectrometry (ICP-OES), and the thermal behaviour of Cd(DDTP $)_{2}$ was investigated by thermogravimetric analysis (TGA). Elemental analysis was carried out using a CHNS-O elemental analyser (Carlo Erba EA 1108, Milan, Italy). UV-vis spectra of the samples dissolved in $\mathrm{CCl}_{4}$ were recorded in the range $200-900 \mathrm{~nm}$ by a UV/visible spectrophotometer (Unicam-UV2-100, Cambridge, UK) using a $1 \mathrm{~cm}$ quartz cell. The IR spectra were recorded on a Fourier transform IR (FTIR) spectrometer (Midac Co. M Series, Costa Mesa, CA, USA) as neat liquid, using a $\mathrm{NaCl}$ cell in the range $400-4000 \mathrm{~cm}^{-1}$. The concentrations of Cadmium were determined by an ICP-OES (Perkin Elmer 2100 DV, Massachusetts, USA) at $228.802 \mathrm{~nm}$. The TG measurement was performed using a thermogravimetric analyser (Shimadzu TGA-50, Kyoto, Japan) with a temperature range from room to $800^{\circ} \mathrm{C}$ at the rate of $20^{\circ} \mathrm{C} \mathrm{min}^{-1}$ under nitrogen $\left(20 \mathrm{~mL} \mathrm{~min}^{-1}\right)$ atmosphere.
2.2. Experiments on Cd(II) Removal from Aqueous Solutions. We have prepared solutions of $\operatorname{HDDTP}\left(2 \cdot 10^{-2} \mathrm{M}\right)$ in the different solvents such as kerosene, benzene, $n$-hexane, petroleum ether, and carbon tetrachloride. The stock solution of cadmium $\left(1 \cdot 10^{-2} \mathrm{M}\right)$ was also prepared in distilled water. All of the chemicals were of analytical reagent grade. Removal of $\mathrm{Cd}$ (II) from aqueous solutions to the organic phase was investigated as a function of $\mathrm{pH}$ for various anions, solvents, extractant concentration, and extraction times. Extraction or contact experiments related effect of time and $\mathrm{pH}$ were performed between 1 and 5 minutes and $\mathrm{pH}$ : 0.5 and 6.0, respectively. Removal of Cd(II) using HDDTP was carried out from different $0.1 \mathrm{M}$ aqueous solution of $\mathrm{NaClO}_{4}, \mathrm{NaCl}$, $\mathrm{NaBr}, \mathrm{NaNO}_{3}$, and $\mathrm{CH}_{3} \mathrm{COONa}$ salts by stirring equal volumes $(25 \mathrm{~mL})$ of $10^{-3} \mathrm{M}$ organic and aqueous phases at room temperature in a conventional separation funnel at different times ( $\mathrm{min}$ ). The $\mathrm{pH}$ values were adjusted by adding sulphuric acid or sodium hydroxide, and the $\mathrm{pH}$ values were measured with a $\mathrm{pH}$ meter (Jenway 3010, London, UK). After separation of the phases, an aliquot of the aqueous part was analysed by an ICP-OES for the particular Cd(II) ion concentrations at $228.802 \mathrm{~nm}$.

The recovery percentage $(R \%)$ of $\mathrm{Cd}(\mathrm{II})$ can be calculated as follows:

$$
R(\%)=\frac{\left[C^{n+}\right]_{0}-\left[C^{n+}\right]}{\left[C^{n+}\right]_{0}} \times 100
$$

where $\left[C^{n+}\right]_{0}$ is initial concentration of the $\mathrm{Cd}(\mathrm{II})$ in the aqueous phase and $\left[C^{n+}\right]$ is the concentration in the aqueous phase after extraction.

\section{Result and Discussion}

3.1. Characterisation of HDDTP and $C d(D D T P)_{2}$. Potentiometric titration of the acid with $0.1 \mathrm{M} \mathrm{NaOH}$ showed that the product contained 98\% HDDTP, which is a yellowishgreen viscous oil. The elemental analysis results for $\left(\mathrm{C}_{9} \mathrm{H}_{19} \mathrm{O}\right)_{2} \mathrm{PSSH}$; Analytical calculated (\%): C, 56.5; $\mathrm{H}$, 10.2; S, 16.7, and found values (\%): C, 56.8; H, 10.3; S, 16.5. Elemental analysis of the recovered white solid Cd(DDTP $)_{2}$ (melting point $28.5^{\circ} \mathrm{C}$ ) was $\mathrm{C}, 49.3$; $\mathrm{H}, 8.7$; S, 14.6; $\mathrm{P}, 7.1$; and $\mathrm{Cd}, 12.8$ for analytical calculations and the found values were found to be $\mathrm{C}, 49.5 ; \mathrm{H}, 8.2 ; \mathrm{S}, 14.4 ; \mathrm{P}, 7.0$; and $\mathrm{Cd}, 12.6$, and the results are in agreement with each other.

The UV-vis absorption spectrum of dinonyldithiophosphoric acid in $\mathrm{CCl}_{4}$ using a $1 \mathrm{~cm}$ quartz cell showed a peak at $267 \mathrm{~nm}$ can be attributed to $n \rightarrow \pi^{*}$ electronic transition related $>\mathrm{P}(=\mathrm{S}) \mathrm{SH}$ group (Table 1 ). The $\mathrm{UV}$-vis absorption 
TABLE 1: The UV-vis. $(\lambda, \mathrm{nm})$ and IR $\left(\widetilde{v}, \mathrm{~cm}^{-1}\right)$ data of HDDTP and Cd(DDTP) 2 .

\begin{tabular}{|c|c|c|c|c|c|c|}
\hline Compound & $\begin{array}{c}\lambda_{\max } \\
\mathrm{nm}\end{array}$ & $\begin{array}{l}(\mathrm{P})-\mathrm{O}-\mathrm{C} \\
\widetilde{v}, \mathrm{~cm}^{-1}\end{array}$ & $\begin{array}{l}\text { P-O-C } \\
\widetilde{v}, \mathrm{~cm}^{-1}\end{array}$ & $\begin{array}{c}(\mathrm{P}=\mathrm{S}) \\
\widetilde{v}, \mathrm{~cm}^{-1}\end{array}$ & $\begin{array}{c}(\mathrm{P}-\mathrm{S}) \\
\widetilde{v}, \mathrm{~cm}^{-1}\end{array}$ & $\begin{array}{c}(\mathrm{S}-\mathrm{H}) \\
\widetilde{v}, \mathrm{~cm}^{-1}\end{array}$ \\
\hline HDDTP & 267 & $1300-940$ & $900-820$ & $740-660$ & 540 & 2550 \\
\hline $\mathrm{Cd}(\mathrm{DDTP})_{2}$ & 294 & $1251-930$ & $838-718$ & $677-649$ & 570 & - \\
\hline
\end{tabular}

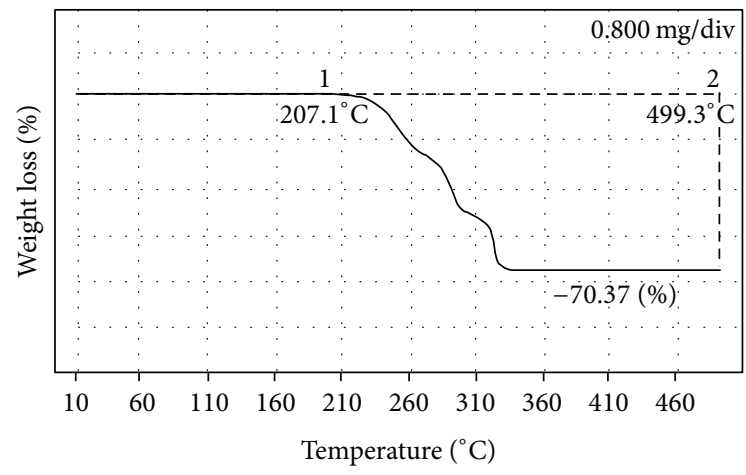

Figure 1: Thermogravimetric analysis of Cd(DDTP $)_{2}$ at a heating rate of $20^{\circ} \mathrm{C} \mathrm{min}^{-1}$ under atmosphere of nitrogen.

spectrum of Cd(DDTP $)_{2}$ was obtained at the same conditions and relevant band was found $294 \mathrm{~nm}$ (Table 1) and can be attributed to the metal-ligand electronic transition.

The recorded IR data of the acid and complex (Table 1) showed a good agreement with earlier studies carried out on other dialkyldithiophosphates $[1,2]$. The IR spectral data of cadmium dinonyldithiophosphate have been recorded at the range of $4000-400 \mathrm{~cm}^{-1}$ (Table 1) and it was observed that the characteristic band of the dinonyldithiophosphoric acid at $2550 \mathrm{~cm}^{-1}$ related to $(\mathrm{P}) \mathrm{S}-\mathrm{H}$ stretching vibration was vanished with the formation of $\mathrm{Cd}(\mathrm{DDTP})_{2}$, and there was no absorption record in the region. Classically, the strong intensity band present in the region $740-660 \mathrm{~cm}^{-1}$ has been attributed to $\mathrm{P}=\mathrm{S}$ double bond and the absorption peak at $\sim 540 \mathrm{~cm}^{-1}$ has been assigned to P-S single bond (Table 1). By formation of the complex, the absorption values of the bands were significantly shifted, and $\mathrm{P}=\mathrm{S}$ peak was shifted down, while $\mathrm{P}-\mathrm{S}$ peak was shifted up. Thus, $\mathrm{P}=\mathrm{S}$ double bond strength was decreased, while P-S single bond strength was increased. This result was in agreement with the previous studies on the other dialkyldithiophosphates $[9,10,13]$. This approach can be easily acceptable for simple $\mathrm{M}^{+}$salt of dithiophosphoric acids; for example, these two bands $(\mathrm{P}=\mathrm{S}$ and $\mathrm{P}-\mathrm{S}$ ) of potassium butyldithiophosphate can be seen at $703 \mathrm{~cm}^{-1}$ and $550 \mathrm{~cm}^{-1}$, respectively [13].

According to the obtained thermogram (Figure 1), $\mathrm{Cd}(\mathrm{DDTP})_{2}$ is stable at temperatures up to $\sim 207^{\circ} \mathrm{C}$ and does not contain water. As shown in Figure 1, Cd(DDTP $)_{2}$ decomposes in three steps, and the main weight loss of the complex takes place between 207 and $332^{\circ} \mathrm{C}$ because of the decomposition of the organic part. The total weight loss percentage of the $\mathrm{Cd}(\mathrm{DDTP})_{2}$ is $70.4 \%$ up to the temperature $499^{\circ} \mathrm{C}$. The weight change is lower than $3 \%$ over $332^{\circ} \mathrm{C}$ temperature. The results are in good agreement with our earlier studies on heavy metal dialkyldithiophosphate complexes [9].

3.2. Cd(II) Removal from Aqueous Solutions. The molar ratio of dinonyldithiophosphoric acid/cadmium has main influence in the extraction process (Table $2(\mathrm{a})$ ). Cd(II) was quantitatively recovered from the acidic aqueous solution under the conditions that the stoichiometric ratio of HDDTP/Cd(II) was $>2 / 1$. When the experiment was performed with lower molar ratio, such as equal volumes of $1 \cdot 10^{-3} \mathrm{M}$ HDDTP, and $1 \cdot 10^{-3} \mathrm{M}$ metal solution was mixed, the removal ratio of $\mathrm{Cd}(\mathrm{II})$ was found to be $60 \%$. A favourable result was obtained, and $\mathrm{Cd}(\mathrm{II})$ was quantitatively extracted from the aqueous solution to organic phase when molar ratio of HDDTP/Cd(II) increased to 3 (Table 2(a)). The $\mathrm{pH}$ experiments on the extraction of Cd(II) showed that (Table 2(b)) it is possible to suggest $\mathrm{Cd}(\mathrm{II})$ can be quantitatively extracted between $\mathrm{pH}$ 0.5 and 6 . The contact time of metal-ligand on the removal of Cd(II) was examined (Table 2(c)), and it was found that 1-minute stirring time can supply quantitative removal of cadmium.

The experiment conducted on different solvents such as kerosene, benzene, $n$-hexane, petroleum ether, and $\mathrm{CCl}_{4}$ implies that there is no difference between solvents used (Table 2(d)). Therefore, all the investigated solvents can be used in the removal of $\mathrm{Cd}(\mathrm{II})$. We have also investigated the effect of common inorganic anions such as $\mathrm{NaClO}_{4}$, $\mathrm{NaCl}, \mathrm{NaBr}, \mathrm{NaNO}_{3}$, and $\mathrm{CH}_{3} \mathrm{COONa}$ on the extractions of $\mathrm{Cd}(\mathrm{II})$ from aqueous solution. We have found that there were no differences except for $\mathrm{CH}_{3} \mathrm{COONa}$ salt (Table 2(e)). Cadmium acetate was also a stable complex and its solubility in water was very high. In addition, our primary results showed that the Cd(II) could not be recovered back by $1-5 \mathrm{M}$ $\mathrm{H}_{2} \mathrm{SO}_{4}$ from organic to aqueous phase.

Our results were in agreement with the studies related to extraction of $\mathrm{Cd}(\mathrm{II})$ by diethy-, dipropyl-, and dibutyl dithiophosphates [10-14]. In these studies they showed that $\mathrm{pH} 3-5$ is suitable for $\mathrm{Cd}(\mathrm{II})$ removal, and they form different $\mathrm{Cd}(\mathrm{II})$ complexes in the basic $\mathrm{pH}$ in order to regenerate from organic phase to aqueous phase. The compounds containing long chain alkyl or more carbon are easily soluble in organic solvents and their solubility in aqueous media decreases. If the results were compared with our findings, the effect of dinonyl group can easily be seen. Cd(DDTP) $)_{2}$ with long nonyl group is insoluble in water and very soluble in organic solvents and 1 minute is sufficient for quantitatively removing of cadmium from aqueous media. There was an acceptable agreement between the previous results and our findings on removing $\mathrm{Cd}(\mathrm{II})$ from aqueous solutions using alkyldithiophosphates as extractants. 
TABLE 2: Determination of removed cadmium from aqueous solutions by dinonyl dithiophosphoric acid. (a) Effect of HDDTP concentration,

(b) influence of $\mathrm{pH}$ of aqueous phase, (c) influence of contact time, (d) effect of solvents, and (e) effect of salts $(\lambda: 228.802 \mathrm{~nm})$.

(a) Effect of HDDTP concentration (pH: 3; time: 3 min.; solvent: kerosene)

\begin{tabular}{lllllll}
\hline HDDTP conc. $\left(10^{-3} \mathrm{M}\right)$ & 0.5 & 1.0 & 2.0 & 3.0 & 4.0 & 5.0 \\
Extraction rate $(\%) \mathrm{Cd}^{++}$ & 28 & 60 & 100 & 100 & 100 & 100 \\
\hline
\end{tabular}

(b) Influence of $\mathrm{pH}$ of aqueous phase (HDDTP: $3 \cdot 10^{-3} \mathrm{M}$; time: 3 min; solvent: kerosene)

\begin{tabular}{lcccccc}
\hline $\mathrm{pH}$ of aqueous phase & 0.5 & 1 & 2 & 3 & 4 & 6 \\
Extraction rate $(\%) \mathrm{Cd}^{++}$ & 100 & 100 & 100 & 100 & 100 & 100 \\
\hline
\end{tabular}

(c) Influence of contact time (HDDTP: $3 \cdot 10^{-3} \mathrm{M}$; $\mathrm{pH}$ : 3; solvent: kerosene)

\begin{tabular}{lccccc}
\hline Time (Min.) & 1 & 2 & 3 & 4 & 5 \\
Extraction rate (\%) $\mathrm{Cd}^{++}$ & 100 & 100 & 100 & 100 & 100 \\
\hline
\end{tabular}

(d) Effect of solvents (HDDTP: 3.10 ${ }^{-3} \mathrm{M} ; \mathrm{pH}$ : 3; time: 3 min)

\begin{tabular}{lccccc}
\hline Solvents & Kerosene & Benzene & $n$-Hexane & Petroleum ether & Carbon-tetrachloride \\
Extraction rate $(\%) \mathrm{Cd}^{++}$ & 100 & 100 & 100 & 100 & 100 \\
\hline
\end{tabular}

(e) Effect of salts (HDDTP: $3 \cdot 10^{-3} \mathrm{M}$; pH: 3; time: 3 min; solvent: kerosene)

\begin{tabular}{lccccc}
\hline Salts $(0.1 \mathrm{M})$ & $\mathrm{NaClO}_{4}$ & $\mathrm{NaCl}$ & $\mathrm{NaBr}$ & $\mathrm{NaNO}_{3}$ & $\mathrm{CH}_{3} \mathrm{COONa}$ \\
Extraction rate $(\%) \mathrm{Cd}^{++}$ & 100 & 100 & 100 & 100 & 0.0 \\
\hline
\end{tabular}

Present results showed that Cd(II) could be easily removed from the acidic aqueous solutions by HDDTP/any organic solvent.

\section{Conclusions}

Dinonyldithiophosphoric acid instantly reacts with $\mathrm{Cd}(\mathrm{II})$ to form a white solid complex at room temperature. The $\mathrm{Cd}(\mathrm{DDTP})_{2}$ is stable up to $\sim 207^{\circ} \mathrm{C}$ and insoluble in water but very soluble in organic solvents such as kerosene, benzene, $n$-hexane, petroleum ether, and carbon tetrachloride and these are suitable solvents for using HDDTP or its salt as extractants.

The experiments concerning the influence of the concentration of HDDTP/any solvent on removal of Cd(II) from the acidic aqueous solutions show that cadmium was quantitatively removed, under the conditions that the stoichiometric ratio of $\mathrm{HDDTP} / \mathrm{Cd}(\mathrm{II}) \geq 2 / 1$. The experiments related with $\mathrm{pH}$ of aqueous media show that $\mathrm{Cd}(\mathrm{II})$ can be removed completely from the acidic solutions at $\mathrm{pH}$ range of $0.5<\mathrm{pH}<$ 6. When the technique is applied on any acidic wastewater or sludge, it does not require any $\mathrm{pH}$ adjustment and the method can supply low costs. Experiments related to effect of contact time for removal of Cd(II) showed that contact of the HDDTP with Cd(II) was sufficient for its quantitative removing. Cd ions were quantitatively transferred to organic phase after 1 min. mixing of $\mathrm{Cd}(\mathrm{II})$ and HDDTP. Because the potential ecological risk of cadmium is relatively high, it is necessary to remove or reduce $\mathrm{Cd}$ (II) levels in the municipal or industrials discharges. It can be concluded that HDDTP is an appropriate substance for removal of $\mathrm{Cd}$ (II) from acidic aqueous solutions.

\section{Conflict of Interests}

The authors declare that there is no conflict of interests regarding the publication of this paper.

\section{References}

[1] J. C. Ramos, A. J. Curtius, and D. L. G. Borges, "Diethyldithiophosphate (DDTP): a review on properties, general applications, and use in analytical spectrometry," Applied Spectroscopy Reviews, vol. 47, no. 8, pp. 583-619, 2012.

[2] A. M. Barnes, K. D. Bartle, and V. R. A. Thibon, "A review of zinc dialkyldithiophosphates (ZDDPS): characterisation and role in the lubricating oil," Tribology International, vol. 34, no. 6, pp. 389-395, 2001.

[3] I. Haiduc, “Thiophosphorus and related ligands in coordination, organometallic and supramolecular chemistry. A personal account," Journal of Organometallic Chemistry, vol. 623, no. 1-2, pp. 29-42, 2001.

[4] T. H. Handley and J. A. Dean, "O,O'-dialkyl phosphorodithioic acids as extractants for metals," Analytical Chemistry, vol. 34, no. 10, pp. 1312-1315, 1962.

[5] B. Gümgüm, N. Biricik, A. Baysal, O. Akba, and G. Öztürk, "Preparation and solvent extraction of nickel complex of $O, O^{\prime}$ dinonyldithiophosphate and its application to spectrophotometric determination of nickel in sediment samples," Annali di Chimica, vol. 96, no. 11-12, pp. 681-688, 2006.

[6] V. F. Toropova, A. R. Garifzyanov, and I. E. Panfilova, "Steric and hydrophobic effects of substituents in extraction of metal complexes with $O, O$-dialkyldithiophosphoric acids," Talanta, vol. 34, no. 1, pp. 211-214, 1987. 
[7] K.-H. Ohrbach, G. Matuschek, A. Kettrup, and A. Joachim, "Simultaneous thermal analysis-mass spectrometry on lubricant systems and additives," Thermochimica Acta, vol. 166, pp. 277-289, 1990.

[8] S. Y. Wu and B. Xie, "Synthesis and spectroscopic properties of (tetraazacyclotetradeca) center dot bis $\left(\mathrm{O}, \mathrm{O}^{\prime}\right.$-bi(1-naphthyl) dithiophosphate) nickel or copper complexes," Chinese Journal of Inorganic Chemistry, vol. 15, no. 2, pp. 267-271, 1999.

[9] N. Biricik and B. Gümgüm, "The preparation and thermoanalytical characterization of heavy metal complexes of $\mathrm{O}, \mathrm{O}^{\prime}$ dinonyldithiophosphate," Thermochimica Acta, vol. 417, no. 1, pp. 43-45, 2004.

[10] X. Ying and Z. Fang, "Experimental research on heavy metal wastewater treatment with dipropyl dithiophosphate," Journal of Hazardous Materials, vol. B137, no. 3, pp. 1636-1642, 2006.

[11] J. S. Carletto, R. M. Luciano, G. C. Bedendo, and E. Carasek, "Simple hollow fiber renewal liquid membrane extraction method for pre-concentration of Cd(II) in environmental samples and detection by Flame Atomic Absorption Spectrometry," Analytica Chimica Acta, vol. 638, no. 1, pp. 45-50, 2009.

[12] R. M. Luciano, G. C. Bedendo, J. S. Carletto, and E. Carasek, "Isolation and preconcentration of Cd(II) from environmental samples using polypropylene porous membrane in a hollow fiber renewal liquid membrane extraction procedure and determination by FAAS," Journal of Hazardous Materials, vol. 177, no. 1-3, pp. 567-572, 2010.

[13] Y. Xu, Z. Xie, and L. Xue, "Chelation of heavy metals by potassium butyl dithiophosphate," Journal of Environmental Sciences, vol. 23, no. 5, pp. 778-783, 2011.

[14] Y. Xu, Y. Chen, and Y. Feng, "Stabilization treatment of the heavy metals in fly ash from municipal solid waste incineration using diisopropyl dithiophosphate potassium," Environmental Technology, vol. 34, no. 11, pp. 1411-1419, 2013.

[15] A. W. Al-Shawi and R. Dahl, "The determination of cadmium and six other heavy metals in nitrate/phosphate fertilizer solution by ion chromatography," Analytica Chimica Acta, vol. 391, no. 1, pp. 35-42, 1999.

[16] J. Duan and B. Su, "Removal characteristics of Cd(II) from acidic aqueous solution by modified steel-making slag," Chemical Engineering Journal, vol. 246, pp. 160-167, 2014.

[17] N. Gupta, D. K. Khan, and S. C. Santra, "An assessment of heavy metal contamination in vegetables grown in wastewaterirrigated areas of Titagarh, West Bengal, India," Bulletin of Environmental Contamination and Toxicology, vol. 80, no. 2, pp. 115-118, 2008.

[18] K. J. Yost, L. J. Miles, and R. A. Greenkorn, "Cadmium: simulation of environmental control strategies to reduce exposure," Environmental Management, vol. 5, no. 4, pp. 341-352, 1981.

[19] G. Yang, L. Tang, X. Lei et al., "Cd(II) removal from aqueous solution by adsorption on $\alpha$-ketoglutaric acid-modified magnetic chitosan," Applied Surface Science, vol. 292, pp. 710-716, 2014.

[20] C. Cheng, J. Wang, X. Yang, A. Li, and C. Philippe, "Adsorption of $\mathrm{Ni}(\mathrm{II})$ and $\mathrm{Cd}(\mathrm{II})$ from water by novel chelating sponge and the effect of alkali-earth metal ions on the adsorption," Journal of Hazardous Materials, vol. 264, pp. 332-341, 2014.

[21] M. Xu, Q. Chang, W. Zhang, and Q. Du, "Removal of cadmium (II) from aqueous solution using chitosan modified with thioglycolic acid," Fresenius Environmental Bulletin, vol. 22, no. 1A, pp. 163-170, 2013.
[22] D. Bingöl, "Removal of cadmium (II) from aqueous solutions using a central composite design," Fresenius Environmental Bulletin, vol. 20, no. 10, pp. 2704-2709, 2011.

[23] G. Edris, Y. Alhamed, and A. Alzahrani, "Biosorption of cadmium and lead from aqueous solutions by Chlorella vulgaris biomass: equilibrium and kinetic study," Arabian Journal for Science and Engineering, vol. 39, no. 1, pp. 87-93, 2014.

[24] C. G. Rocha, D. A. M. Zaia, R. V. D. S. Alfaya, and A. A. D. S. Alfaya, "Use of rice straw as biosorbent for removal of $\mathrm{Cu}(\mathrm{II})$, $\mathrm{Zn}(\mathrm{II}), \mathrm{Cd}(\mathrm{II})$ and $\mathrm{Hg}(\mathrm{II})$ ions in industrial effluents," Journal of Hazardous Materials, vol. 166, no. 1, pp. 383-388, 2009.

[25] Y. Zheng, C. Xiong, C. Yao et al., "Adsorption performance and mechanism for removal of $\mathrm{Cd}(\mathrm{II})$ from aqueous solutions by D001 cation-exchange resin," Water Science \& Technology, vol. 69, no. 4, pp. 833-839, 2014.

[26] A. M. Atta, H. S. Ismail, and A. M. Elsaaed, "Application of anionic acrylamide-based hydrogels in the removal of heavy metals from waste water," Journal of Applied Polymer Science, vol. 123, no. 4, pp. 2500-2510, 2012.

[27] Y. Shengke and C. Yuyun, "Synergistic effects of chelating precipitation and flocculation on removal of cadmium aminocomplex from wastewater," Fresenius Environmental Bulletin, vol. 20, no. 12, pp. 3235-3240, 2011. 

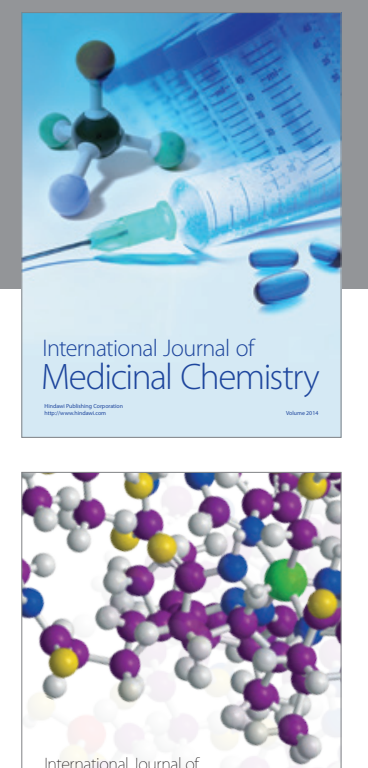

\section{Carbohydrate} Chemistry

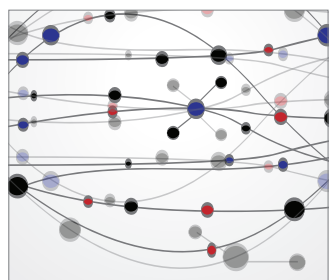

The Scientific World Journal
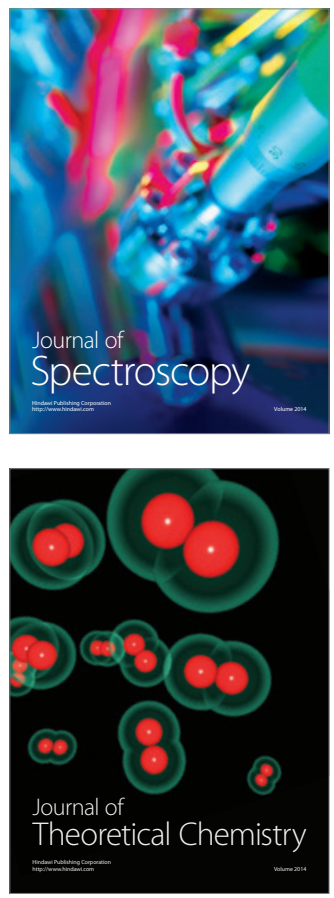
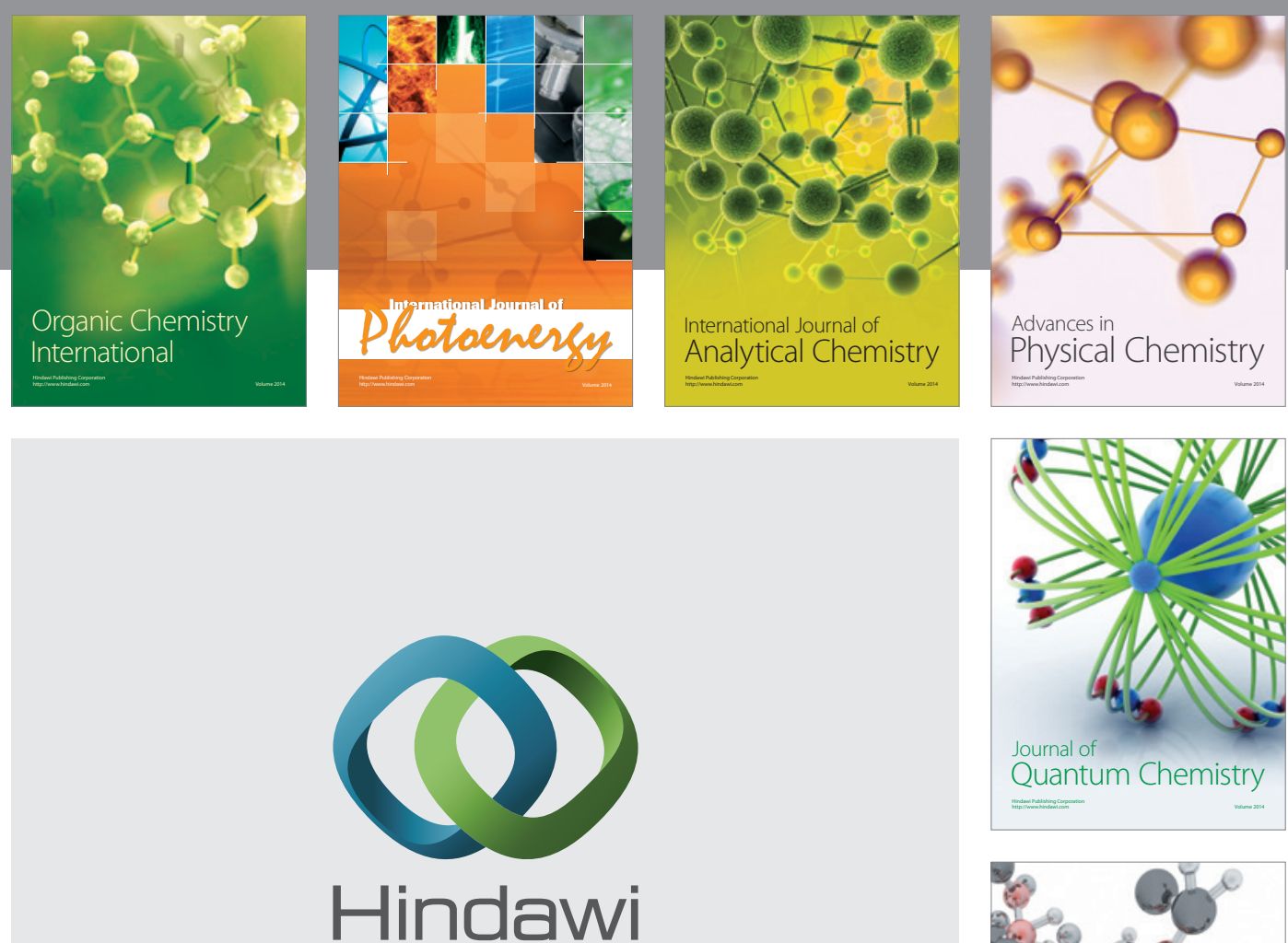

Submit your manuscripts at

http://www.hindawi.com

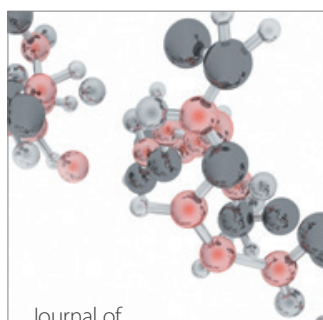

Analytical Methods

in Chemistry

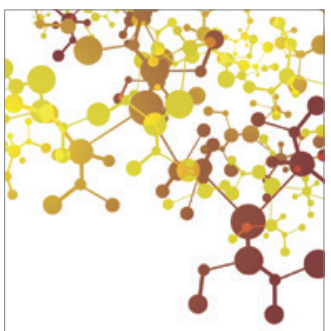

Journal of

Applied Chemistry

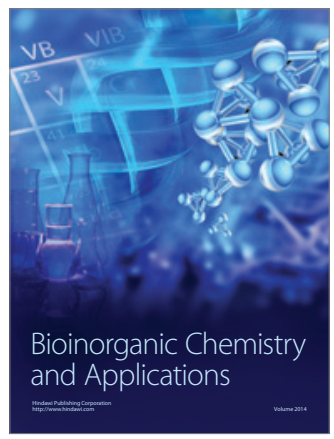

Inorganic Chemistry
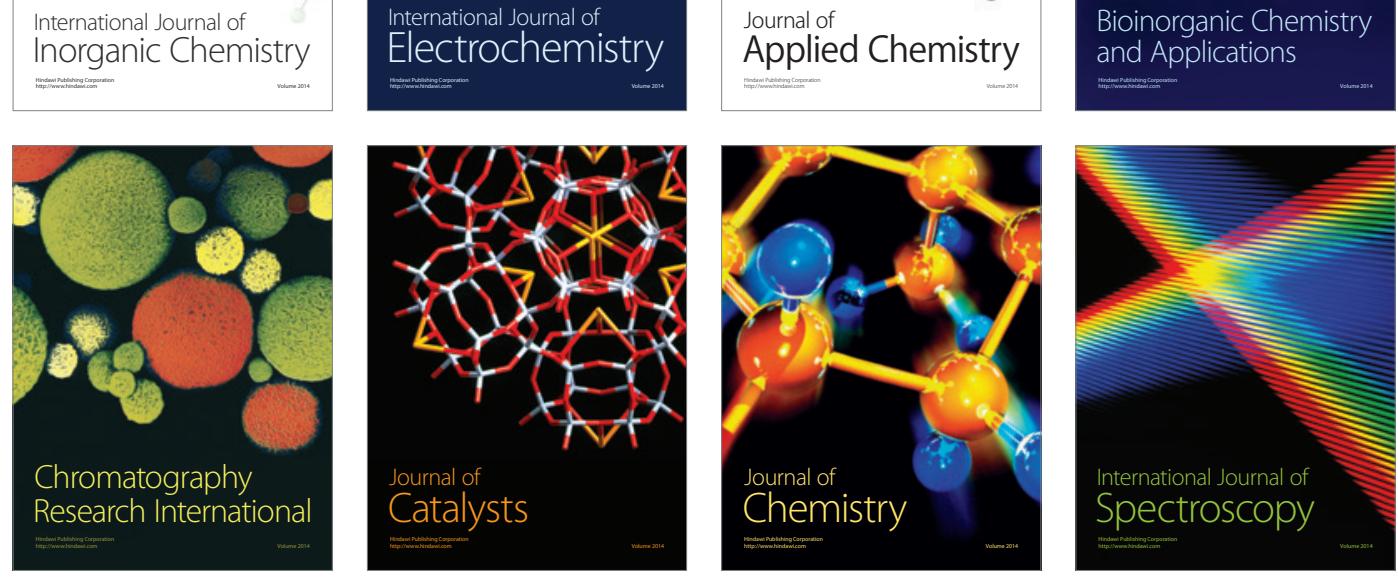